Reviu Akuntansi dan Bisnis Indonesia, Vol. 3 No. 2, Hlm: 163-178, Desember 2019

Website: http://journal.umy.ac.id/index.php/rab

\title{
Pengaruh Biological Asset Intensity, Ukuran Perusahaan, Pertumbuhan Perusahaan, Konsentrasi Kepemilikan Manajerial, dan Jenis KAP Terhadap Pengungkpan Aset Biologis (Pada Perusahaan Agrikultur yang Terdaftar di Bursa Efek Indonesia Periode 2014-2017)
}

\author{
Linda Kurnia Alfiani * Evi Rahmawati \\ Program Studi Akuntansi Universitas Muhammadiyah Yogyakarta
}

I N F O A R T I K E L

\section{Kata Kunci:}

Biological Asset Intensity,

Ukuran Perusahaan,

Pertumbuhan Perusahaan,

Konsentrasi Kepemilikan

Manajerial, Jenis KAP,

Pengungkapan Aset

Biologis.

Jenis Artikel:

Penelitian Empiris

Correspondence:

alfianilinda14@gmail.com

\begin{abstract}
A B S TRAK
Penelitian ini bertujuan untuk menguji dan menganalisis Pengaruh Biological Asset Intensity, Ukuran Perusahaan, Pertumbuhan Perusahaan, Konsentrasi Kepemilikan Manajerial, dan Jenis KAP terhadap Pengungkapan Aset Biologis. Populasi yang digunakan dalam penelitian ini yaitu perusahaan agrikultur yang terdaftar di Bursa Efek Indonesia (BEI) periode 2014-2017. Data yang digunakan dalam penelitian ini adalah data sekunder yang berupa data kuantitatif dari laporan keuangan perusahaan agrikultur yang terdaftar di Bursa Efek Indonesia (BEI) periode 2014-2017. Penelitian ini menggunakan metode purposive sampling dalam pengambilan sampelnya, dan diperoleh sampel sejumlah 72 sampel. Metode analisis yang digunakan dalam penelitian ini yaitu menggunakan analisis regresi linier berganda. Berdasarkan analisis yang telah dilakukan diperoleh hasil penelitian yang menunjukkan bahwa biological asset intensity, ukuran perusahaan, dan pertumbuhan perusahaan tidak berpengaruh terhadap pengungkapan aset biologis. Konsentrasi kepemilikan manajerial, dan jenis KAP berpengaruh positif terhadap pengungkapan aset biologis.
\end{abstract}

(C) 2019 RAB. Published by Universitas Muhammadiyah Yogyakarta

\section{PENDAHULUAN}

Perusahaan yang bergerak di sektor agrikultur memiliki peran yang sangat penting dalam bidang pertanian di Indonesia. Indonesia merupakan negara yang kaya akan sumber daya alamnya dan dikenal sebagai negara agraris karena memiliki wilayah yang sangat potensial untuk dikembangkan usaha di bidang pertanian. Indonesia merupakan negara yang terletak di garis khatulistiwa dan beriklim tropis. Sektor pertanian memiliki peran yang sangat penting bagi bangsa Indonesia karena sebagian besar mata pencaharian penduduk di Indonesia ada pada sektor pertanian. Oleh sebab itu, bangsa Indonesia seharusnya menjadi negara yang maju dalam bidang pertanian.

Dilihat dari potensi sumber daya alamnya, bangsa Indonesia seharusnya mampu untuk memenuhi kebutuhan pangan bangsanya dan mengurangi kegiatan impor hasil pertanian. Oleh sebab itu, sektor agrikultur harus terus dikembangkan karena sektor tersebut sangat penting dalam menunjang perekonomian di Indonesia. Untuk mengembangkan sektor agrikultur, harus ada 
perhatian yang lebih dari beberapa pihak terutama perusahaan agrikultur, pemerintah, dan masyarakat.

Pengembangan pada sektor agrikultur harus didukung oleh ketersediaan informasi. Informasi tersebut disajikan dalam bentuk laporan keuangan yang akan digunakan oleh pihak internal dan pihak eksternal. Ketersediaan informasi merupakan hal yang penting dalam pengambilan keputusan. Pengambilan keputusan tersebut dipengaruhi oleh kualitas pengungkapan perusahaan melalui laporan tahunan (annual report). Penyajian laporan keuangan harus disertai dengan pengungkapan agar terhindar dari kesalahan dalam menyajikan informasi. Sebuah perusahaan harus memiliki nilai lebih dalam mengungkapkan informasi yang disajikan dalam laporan keuangan tahunan (annual report) dibandingkan perusahaan lain agar mampu menghadapi dan memenangkan persaingan.

Pengungkapan laporan keuangan yaitu penyampaian (release) informasi ekonomi yang menggambarkan kinerja dan posisi keuangan suatu perusahaan (Owusu-Ansah 1998). Sebuah perusahaan harus memiliki pengungkapan laporan keuangan yang berkualitas dan menyajikan pengungkapan informasi yang memiliki nilai jual yang tinggi untuk mempermudah sekaligus menarik perhatian investor dan pemakai yang berkepentingan lainnya (Choi, 2005).

Menurut Financial Accounting Standard Board (1984) aset merupakan manfaat ekonomi yang mungkin akan terjadi di masa depan yang didapatkan dan dikendalikan oleh entitas tertentu yang diakibatkan peristiwa ataupun transaksi masa lalu. Perusahaan yang bergerak pada sektor agrikultur menurut standar meliputi pertanian, peternakan, perikanan, perkebunan, kehutanan, tanaman khusus, dan kebun buah-buahan. International Accounting Standard 41 (IAS 41) yang mengatur akuntansi pada sektor agrikultur menjelaskan yang dimaksud dengan aset biologis adalah aset yang berupa hewan atau tanaman hidup (biological asset is a living animal or plant). Aset biologis yang dimiliki oleh perusahaan agrikultur dalam aktivitasnya memiliki karakteristik aset yang unik karena mengalami proses biologis mulai dari pertumbuhan, degenerasi, produksi, dan prokreasi yang disebabkan oleh perubahan kualitatif dan kuantitatif pada makhluk hidup dan menghasilkan aset baru dalam bentuk agrikultur atau aset biologis tambahan pada jenis yang sama.

PSAK 69 mengatur bahwa aset biologis atau produk agrikultur diakui saat memenuhi beberapa kriteria yang sama dengan kriteria pengakuan aset. Pengakuan aset tersebut terjadi pada saat pengakuan awal dan akhir periode pelaporan keuangan pada nilai wajar yang dikurangi biaya untuk menjual. Selisih yang timbul dari perubahan nilai wajar aset diakui dalam laba rugi periode terjadinya.

\section{TINJAUAN LITERATUR DAN PERUMUSAN HIPOTESIS}

\section{Teori Keagenan (Agency Theory)}

Teori keagenan yaitu teori yang mengungkapkan bahwa manajer yang memiliki peran sebagai agen diberikan tugas oleh pemegang saham yang berperan sebagai principal untuk melakukan sebuah jasa dan wewenang dalam pengambilan sebuah keputusan perusahaan (Jensen and Meckling 1976). Dalam melaksanakan tugasnya, terkadang manajer tidak membuat keputusan yang sesuai dengan kepentingan pemegang saham (principal). Sistem kepemilikan seperti ini akan memunculkan asimetri informasi karena terdapat perbedaan kepentingan antara manajer dengan pemegang saham. Perbedaan kepentingan tersebut mengakibatkan manajer melakukan manajemen laba (Sefiana, 2009).

Menurut Kiryanto dan Supriyanto (2006) asimetri informasi yang terjadi antara manajer dengan pemegang saham mengakibatkan manajer menyajikan informasi yang berbeda dengan informasi yang sebenarnya, terutama informasi tentang pengukuran kinerja manajemen. Asimetri informasi yang terjadi antara manajer dan pemegang saham dapat dikurangi dengan cara mengungkapkan secara lengkap dan sukarela mengenai informasi yang berkaitan dengan perusahaan. 


\section{Teori Stakeholders (Stakeholders Theory)}

Menurut Freedman and Jaggi (1984) individu atau kelompok yang dapat dipengaruhi ataupun memengaruhi proses pencapaian tujuan sebuah perusahaan disebut dengan stakeholders. Teori stakeholders menyatakan bahwa perusahaan harus memberikan manfaat bagi stakeholders (pemegang saham, kreditor, konsumen, supplier, pemerintah, masyarakat, analis, dan pihak lain) yang tidak hanya beroperasi untuk kepentingannya sendiri. Salah satu hal yang memengaruhi keberadaan dari sebuah perusahaan yaitu dukungan dari stakeholders (Ghozali and Chariri, 2007).

Teori Stakeholders menyatakan bahwa seluruh pemangku kepentingan (stakeholders) mendapatkan hak untuk diberikan informasi tentang kegiatan perusahaan yang memengaruhi mereka (Putri, 2011). Dalam mencapai tujuan perusahaan, manajemen perusahaan berperan untuk menilai pentingnya pemenuhan kebutuhan stakeholders. Perusahaan akan memiliki nilai jual yang tinggi ketika perusahaan mengungkapkan lebih banyak informasinya karena investor cenderung lebih tertarik untuk menanamkan modalnya ke perusahaan yang lebih banyak dan lengkap dalam mengungkapkan informasinya. Teori stakeholders menjelaskan bahwa sebuah perusahaan cenderung lebih banyak mengungkapkan informasinya ketika perusahaan tersebut memiliki konsentrasi kepemilikan yang rendah dan adanya kelompok pemangku kepentingan yang sangat beragam (Cornier, et al., 2005).

\section{Aset Biologis}

\section{Pengertian Aset Biologis}

Menurut IAS 41, aset biologis adalah aset yang berupa hewan atau tanaman hidup (biological asset is a living animal or plant). Aset biologis jika dilihat dari karakteristik asetnya merupakan aset yang berupa hewan ternak atau tanaman pertanian yang dimiliki oleh perusahaan agrikultur yang berasal dari peristiwa ataupun kegiatan masa lalu (Abdullah 2011).

Kategori Aset Biologis

Menurut IAS 41, jenis-jenis aset biologis jika dilihat berdasarkan ciri-ciri yang melekat pada asetnya, terdiri dari aset bahan pokok yang merupakan aset agrikultur yang menghasilkan bahan pokok seperti padi yang menghasilkan beras, produksi kayu yang dijadikan kertas, dan hewan ternak yang diproduksi dagingnya. Kemudian, aset biologis bawaan yang dapat dipanen tetapi tidak menghasilkan produk agrikultur utama dari perusahaan karena aset tersebut dapat beregenerasi sendiri, seperti pohon yang buahnya dapat dipanen ataupun produksi wol dari ternak domba.

\section{Transformasi Biologis}

Menurut IAS 41, transformasi biologis yaitu aset biologis yang akan terus mengalami perubahan atau pertumbuhan (bertambahnya kualitas atau peningkatan kuantitas), degenerasi (penurunan kualitas atau kuantitas), prokreasi (menciptakan tumbuhan baru), dan produksi (menghasilkan produk baru). Dengan adanya transformasi biologis tersebut menyebabkan terjadinya perubahan kualitas dan kuantitas pada aset biologis.

Tumbuhan ataupun hewan yang masih tumbuh dan berkembang dapat dikatakan sebagai aset biologis, sedangkan ketika aset tersebut bertelur, diterminasi (ditebang dan dimanfaatkan hingga habis), dan berubah maka penyebutan aset biologis tersebut berubah menjadi hasil peternakan atau pertanian (Martani, 2011).

Pengungkapan Aset Biologis

Posisi dan kinerja perusahaan dapat dilihat dari pengungkapan yang dilakukan oleh perusahaan tersebut. Pengungkapan merupakan informasi ekonomi yang dimiliki suatu perusahaan 
(Owusu-Ansah 1998). Menurut IAS 41, konsep-konsep yang terdapat dalam pengungkapan yaitu pengungkapan cukup yang diwajibkan oleh standar akuntansi yang berlaku, kemudian pengungkapan wajar yang memiliki konsep lebih positif karena bersifat umum dan memberikan perlakuan yang sama untuk semua pemakai laporan keuangan. Selain itu, juga ada pengungkapan penuh. Item pengungkapan aset biologis dengan PSAK 69 terdapat dalam appendix 1. Menurut IAS 41, perusahaan harus melakukan pengungkapan-pengungkpan sebagai berikut:

1. Penentuan penggunaan metode dan asumsi seperti pada pengukuran aset biologis berdasarkan IAS 41, pengukurannya harus menggunakan nilai wajar.

2. Pengungkapan keberadaan dan nilai tercatat atas aset biologis yang dijadikan jaminan utang.

3. Laporan keuangan harus mengungkapkan besarnya komitmen untuk pelaksanaan pengembangan atau untuk akuisisi aset biologis, serta strategi yang digunakan oleh entitas atas kegiatan agrikulturnya.

4. Laporan keuangan mengakui dan mengungkapkan hibah pemerintah yang berupa hasil alam dan besarnya dana yang diberikan oleh pemerintah, ketidakpastian dana pemerintah tersebut, penurunan dalam jumlah signifikan yang diharapkan dalam tingkatan hibah.

5. Daftar perubahan rekonsiliasi dalam nilai tercatat pada aset biologis harus disajikan oleh perusahaan di antara awal dan akhir periode berjalan, hal ini meliputi keuntungan dan kerugian atas aset biologis, kenaikan jumlah aset karena adanya penjualan dan telah dikualifikasikan sebagai aset siap jual, penurunan jumlah aset karena panen dan telah menjadi produk agrikultural, timbulnya selisih kurs, dan perubahan-perubahan lainnya.

6. Jika tidak diungkapkan di tempat lain di informasi yang dipulikasikan laporan keuangan.

7. Deskripsi dari setiap kelompok aset biologis.

8. Nilai wajar dikurang untuk menjual dari produk agrikultural yang telah dipanen selama periode tertentu.

9. Aset yang dikonsumsi adalah aset yang akan dipanen sebagai hasil pertanian, sedangkan aset pembawa adalah aset selain dari aset biologis tersebut.

Biological asset intensity berpengaruh positif terhadap pengungkapan aset biologis

Aset biologis merupakan aset yang berupa makhluk hidup atau tanaman hidup yang mengalami transformasi biologis akibat dari peristiwa ataupun kegiatan masa lalu yang memberikan manfaat untuk perusahaan di masa yang akan datang. Transformasi biologis tersebut berupa perubahan nilai aset melalui kenaikan (peningkatan kualitas dari hewan atau tanaman), penurunan (pengurangan atau penurunan kualitas hewan atau tanaman), prokreasi (perkembangbiakan), dan produksi.

Biological asset intensity (intensitas aset biologis) merupakan jumlah proporsi investasi pada aset biologis perusahaan agrikultur yang disajikan dalam catatan atas laporan keuangan. Biological asset intensity pada perusahaan agrikultur menggambarkan besaran proporsi investasi yang dimiliki perusahaan terhadap aset biologisnya (PSAK 69). Tingkat pengungkapan aset biologis akan meningkat searah dengan peningkatan intensitas aset biologisnya (Amelia, 2017).

Tingkat intensitas aset biologis searah dengan tingkat pengungkapan aset biologis. Oleh sebab itu, ketika intensitas aset biologis naik, maka tingkat pengungkapan aset biologisnya akan meningkat. Semakin tinggi atau banyak investasi perusahaan agrikultur terhadap aset biologisnya, maka akan semakin banyak dan luas tingkat pengungkapannya. Perusahaan yang lebih banyak mengungkapkan informasi cenderung mendapatkan perhatian yang lebih dari pihak luar, salah satunya yaitu investor. Investor lebih tertarik untuk menanamkan modalnya pada perusahaan yang lebih banyak dan lebih luas dalam mengungkapkan informasinya.

Menurut penelitian terdahulu yang dilakukan Silva, dkk (2012) pelaporan aset biologis merupakan penegasan kepatuhan pengungkapan yang dilakukan oleh perusahaan dalam memberikan informasi kepada pengguna laporan keuangan. Penelitian terdahulu yang dilakukan oleh Rute and Patricia (2014), Amelia (2017), dan Kusumadewi (2018) menunjukkan bahwa 
biological asset intensity berpengaruh terhadap pengungkapan aset biologis. Berdasarkan uraian tersebut, hipotesis pertama yang akan diuji dalam penelitian ini adalah sebagai berikut:

\section{$H_{t} \quad$ : Biological asset intensity berpengaruh positif terhadap pengungkapan aset biologis}

Ukuran perusahaan berpengaruh positif terhadap pengungkapan aset biologis

Ukuran perusahaan merupakan pengklasifikasian perusahaan menjadi perusahaan kecil ataupun besar yang dihitung menggunakan suatu skala dengan cara total aset perusahaan, rata-rata tingkat penjualan, jumlah penjualan, dan nilai pasar saham (Machfoedz, 1994). Presentase biaya dan modal agensi yang besar terjadi pada perusahaan besar (Jensen and Meckling 1976).

Perusahaan besar memiliki banyak keuntungan, salah satunya yaitu mendapatkan banyak perhatian dari pihak eksternal. Perusahaan besar memiliki akses yang besar dalam melakukan ekspansi bisnis, salah satunya yaitu ke sumber-sumber pendanaan baik perbankan maupun pasar modal untuk membiayai investasinya dalam meningkatkan laba perusahaan. Selain itu, perusahaan besar cenderung akan mempertahankan stabilitas dan kinerja demi keberlangsungan perusahaannya karena banyak diawasi oleh pihak eksternal, salah satunya yaitu investor (Setiawan 2009).

Pengungkapan informasi sangat dipengaruhi oleh ukuran perusahaan karena perusahaan yang besar cenderung memiliki sumber daya yang besar. Sumber daya yang dimiliki oleh perusahaan tersebut digunakan untuk menyediakan informasi yang akan digunakan sebagai bahan untuk keperluan pengungkapan informasi kepada pihak eksternal sehingga tidak memerlukan biaya lagi untuk mengungkapkan informasinya secara lengkap. Pengungkapan informasi yang disajikan oleh perusahaan besar cenderung lebih banyak dan luas dibandingkan dengan pengungkapan informasi yang disajikan oleh perusahaan kecil karena perusahaan kecil tidak memiliki sumber daya sebesar yang dimiliki oleh perusahaan besar. Oleh sebab itu, biaya yang diperlukan perusahaan kecil untuk mengungkapkan informasinya akan lebih besar dan menyebabkan perusahaan kecil berada dalam situasi persaingan ketat yang akan mengancam keberlangsungan perusahaannya.

Tingkat pengungkapan informasi yang tinggi yang dilakukan oleh perusahaan besar menyebabkan perusahaan besar lebih banyak disorot dan diperhitungkan oleh para investor. Investor cenderung lebih tertarik menanamkan modalnya ke perusahaan yang mengungkapkan lebih banyak informasi.

Penelitian terdahulu yang dilakukan oleh Amelia (2017) dan Rute and Patricia (2014) menunjukkan bahwa ukuran perusahaan berpengaruh terhadap pengungkapan aset biologis. Penelitian yang dilakukan oleh Nuryaman (2009) juga menunjukkan hasil bahwa ukuran perusahaan berpengaruh terhadap pengungkapan sukarela. Berdasarkan uraian tersebut, hipotesis kedua yang akan diuji dalam penelitian ini adalah sebagai berikut:

\section{$\boldsymbol{H}_{2:}$ Ukuran perusahaan berpengaruh positif terhadap pengungkapan aset biologis}

Pertumbuhan perusahaan berpengaruh positif terhadap pengungkapan aset biologis

Pertumbuhan perusahaan merupakan kompetensi perusahaan dalam meningkatkan size (Kallapur and Trombley, 2001). Kemampuan sebuah perusahaan untuk mendapatkan laba yang tinggi menyebabkan investor mengharapkan return yang semakin besar. Perusahaan yang memiliki pertumbuhan yang tinggi cenderung lebih diperhitungkan dan dipertimbangkan oleh investor untuk menanamkan modalnya ke perusahaan tersebut. Oleh sebab itu, pertumbuhan sebuah perusahaan sangat berpengaruh terhadap nilai perusahaan (Soliha dan Taswan, 2002).

Perusahaan yang memiliki tingkat pertumbuhan yang tinggi cenderung lebih banyak mendapatkan sorotan, sehingga perusahaan tersebut akan melakukan pengungkapan tanggung jawab sosial yang lebih banyak (Sari 2012). Pertumbuhan perusahaan pada sektor agrikultur 
merupakan kemampuan yang dimiliki oleh perusahaan agrikultur untuk meningkatkan aset perusahaannya. Pertumbuhan perusahaan agrikultur menggambarkan tingkat perluasan usaha yang dilakukan oleh perusahaan tersebut dengan melihat pertumbuhan aktiva yang digunakan dalam kegiatan operasional. Perusahaan yang memiliki pertumbuhan yang tinggi cenderung lebih banyak mendapatkan pengawasan dari pihak eksternal, terutama investor karena dianggap dapat memberikan profitabilitas yang tinggi di masa depan. Oleh sebab itu, perusahaan yang memiliki tingkat pertumbuhan yang tinggi akan lebih banyak dan luas dalam mengungkapkan informasinya untuk menarik perhatian investor dalam mengambil keputusan untuk menanamkan modalnya ke perusahaan tersebut.

Penelitian terdahulu yang dilakukan oleh Effendi dan Hapsari (2015), Amelia (2016), Munsaidah, dkk (2016) menunjukkan bahwa pertumbuhan perusahaan berpengaruh terhadap pengungkapan Corporate Social Responsibility (CSR). Berdasarkan uraian tersebut, hipotesis ketiga yang akan diuji dalam penelitian ini adalah sebagai berikut:

\section{$\boldsymbol{H}_{\boldsymbol{s}} \quad$ :Pertumbuhan perusahaan berpengaruh positif terhadap pengungkapan aset biologis}

Konsentrasi kepemilikan manajerial berpengaruh positif terhadap pengungkapan aset biologis

Kepemilikan manajerial merupakan suatu kondisi di mana manajer yang memiliki peran ganda sebagai agen dan juga sebagai principal (Christiawan dan Tarigan, 2007). Kepemilikan manajerial adalah tingkat kepemilikan saham yang dimiliki oleh pihak manajemen dan aktif dalam setiap pengambilan keputusan, diukur oleh rasio saham yang dimiliki oleh manajer pada akhir tahun dan dinyatakan dalam persentase (Aprianingsih 2016). Kinerja dan nilai suatu perusahaan selalu diupayakan oleh manajer agar selalu meningkat. Meningkatnya kinerja dan nilai perusahaan akan meningkatkan kekayaan yang dimiliki pemegang saham, sehingga kesejahteraan pemegang saham juga akan meningkat (Pratiwi 2014).

Konsentrasi kepemilikan sangat erat hubungannya dengan teori agensi. Menurut Jensen and Meckling (1976) ketika pemilik saham (principal) mempekerjakan manajer (agent) untuk menjalankan sebuah perusahaan, maka terjadilah masalah agensi. Masalah agensi tersebut terjadi karena adanya perbedaan kepentingan antara manajer dengan pemilik saham. Perbedaan kepentingan tersebut mendorong manajer untuk melakukan aktivitas yang dapat memberikan keuntungan untuk dirinya sendiri, seperti empire building, melalaikan tanggung jawab, dan menyajikan informasi laba perusahaan secara berlebihan. Oleh karena itu, terdapat kemungkinan bahwa manajer tidak memberikan informasi kepada pihak eksternal demi keuntungan pribadinya sendiri.

Kepemilikan manajerial merupakan salah satu cara untuk mengurangi konflik kepentingan dalam perusahaan. Meningkatkan kepemilikan manajerial akan menyeimbangkan status kekayaan yang dimiliki oleh manajemen secara pribadi dengan kekayaan yang dimiliki oleh perusahaan, sehingga manajemen akan berusaha untuk mengurangi berbagai macam risiko untuk menyelamatkan kekayaan tersebut, bahkan akan berusaha untuk selalu meningkatkan laba (Jensen and Meckling 1976).

Kepemilikan manajerial dapat menjadikan perusahaan semakin berkembang dan memiliki kinerja yang lebih baik. Dengan adanya kepemilikan manajerial, tidak ada lagi konflik kepentingan antara manajer dengan pemegang saham karena manajer yang sekaligus berperan sebagai pemegang saham akan bekerja secara optimal dan tidak hanya mementingkan kepentingannya sendiri. Oleh sebab itu, dengan adanya kepemilikan manajerial dapat meningkatkan nilai dan kinerja perusahaan sehingga menjadikan perusahaan lebih berkembang. Perusahaan yang memiliki nilai dan kinerja yang baik akan semakin banyak mengungkapkan informasinya. Pengungkapan informasi yang banyak dan luas dapat mengundang investor untuk menanamkan modalnya ke perusahaan tersebut.

Penelitian terdahulu yang dilakukan oleh Aini dan Syafruddin (2015) menunjukkan bahwa kepemilikan manajerial berpengaruh terhadap pengungkapan sukarela. Kemudian penelitian yang dilakukan oleh 'Amal (2011) dan Edison (2017) menunjukkan bahwa kepemilikan manajerial 
berpengaruh terhadap pengungkapan Corporate Social Responsibility (CSR). Berdasarkan uraian tersebut, hipotesis keempat yang akan diuji dalam penelitian ini adalah sebagai berikut:

\section{$\boldsymbol{H}_{4}$ : Konsentrasi kepemilikan manajerial berpengaruh positif terhadap pengungkapan aset biologis}

Jenis KAP berpengaruh positif terhadap pengungkapan aset biologis

Salah satu cara untuk mengurangi besarnya biaya agensi yaitu dengan melakukan auditing (Jensen and Meckling 1976). Salah satu cara untuk mengurangi information gap dan meningkatkan kredibilitas pengungkapan informasi secara sukarela yang dikeluarkan oleh perusahaan yaitu dengan melakukan proses auditing. Manajer akan percaya untuk mengungkapkan lebih banyak informasi perusahaannya jika kantor akuntan tersebut merupakan kantor akuntan yang besar, diketahui, ataupun terkenal (Widowati, 2011). Setiap Kantor Akuntan Publik (KAP) memiliki standar pengungkapan yang berbeda-beda sehingga pengungkapan yang dihasilkan juga berbeda.

Organisasi yang menawarkan jasa profesional dalam praktik akuntan publik yang telah mendapatkan izin berdasarkan peraturan perundang-undangan yang berlaku disebut dengan Kantor Akuntan Publik (Rachmawati 2008). Auditor dari Kantor Akuntan Publik Big Four dianggap lebih banyak dan lebih luas dalam mengungkapkan informasi dari perusahaan yang diaudit dibandingkan dengan auditor dari Kantor Akuntan Publik non-Big Four.

Kantor Akuntan Publik Big Four merupakan auditor besar yang memiliki reputasi dan independensi yang tinggi sehingga memberikan kualitas yang tinggi pada hasil auditnya. Kualitas auditor dipandang sebagai kemampuan untuk meningkatkan kualitas laporan keuangan bagi perusahaan yang diaudit. Oleh sebab itu, auditor yang memiliki kualitas yang tinggi diharapkan dapat meningkatkan kepercayaan investor untuk menanamkan modalnya ke perusahaan yang diaudit.

Penelitian terdahulu yang dilakukan oleh Hodgdon, dkk (2009) dan Nuryaman (2009) menunjukkan bahwa terdapat hubungan antara kepatuhan pengungkapan dengan perusahaan yang diaudit oleh Kantor Akuntan Publik Big Four. Berdasarkan uraian tersebut, hipotesis kelima yang akan diuji dalam penelitian ini adalah sebagai berikut:

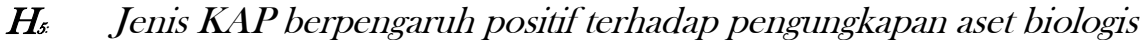

\section{METODE PENELITIAN}

Objek Penelitian

Objek atau populasi yang digunakan dalam penelitian ini adalah perusahaan agrikultur yang terdaftar di Bursa Efek Indonesia (BEI). Sampel yang digunakan dalam penelitian ini adalah seluruh perusahaan agrikultur yang terdaftar di Bursa Efek Indonesia (BEI) periode 2014-2017.

Jenis Data

Penelitian ini menggunakan data sekunder berupa data kuantitatif dari laporan keuangan tahunan (annual report) perusahaan agrikultur yang terdaftar di Bursa Efek Indonesia (BEI) periode 2014-2017. 


\section{Teknik Pengambilan Sampel}

Penelitian ini menggunakan metode purposive sampling karena tidak semua sampel mempunyai kriteria yang peneliti tentukan. Kriteria-kriteria yang peneliti tentukan dalam pengambilan sampel menggunakan purposive sampling yaitu:

1. Perusahaan agrikultur yang terdaftar di Bursa Efek Indonesia (BEI) periode 2014-2017 yang laporan keuangan tahunannya (annual report) telah dipublikasikan secara lengkap.

2. Laporan keuangan tahunan (annual report) dinyatakan dalam mata uang rupiah (Rp).

Teknik Pengumpulan Data

Penelitian ini menggunakan metode dokumenter yang diperoleh dengan melakukan pengumpulan data-data berupa dokumen laporan keuangan tahunan (annual report) perusahaan agrikultur yang terdapat dalam Bursa Efek Indonesia (BEI). Penelitian ini juga menggunakan library research atau kepustakaan dengan melakukan pengumpuan data-data dari berbagai sumber pustaka untuk mendukung penelitian ini.

Definisi Operasional Variabel Penelitian

1. Variabel Dependen

Pengungkapan Aset Biologis (Y)

Pengungkapan aset biologis merupakan variabel dependen yang digunakan dalam penelitian ini. Item pengungkapan aset biologis terdapat dalam appendix 1. Indeks pengungkapan untuk mengukur luas pengungkapan aset biologis yaitu dengan memberi skor 1 (satu) pada setiap item yang diungkap dalam laporan keuangan yang telah diaudit, dan memberi skor 0 (nol) jika tidak diungkapkan. Pengukuran luas pengungkapan aset biologis menggunakan rumus indeks Wallace sebagai berikut:

Keterangan:

$$
\text { Pengungkapan Aset Biologis }=\mathrm{x} 100 \%
$$

$\mathrm{n} \quad=$ total skor yang diperoleh

$34=$ total skor yang diwajibkan menurut PSAK 69

2. Variabel Independen

a. Biological Asset Intensity (X1)

Pengukuran intensitas aset biologis yang digunakan dalam penelitian Rute and Patricia (2014) yaitu:

Keterangan:

$$
\text { Biological Asset Intensity }=\frac{\text { Aset Biologis }}{\text { Total Aset }}
$$

Aset Biologis = aset hewan atau tanaman hidup yang dimiliki oleh perusahaan agrikultur

Total Aset = total aset yang dimiliki perusahaan agrikultur

b. Ukuran Perusahaan (X2)

Pengukuran yang digunakan untuk menghitung ukuran perusahaan menggunakan rumus sebagai berikut:

$$
\text { Size }=\text { Ln (Total Aset })
$$


Keterangan:

Ln $($ Total Aset $)=$ Logaritma dari total aktiva

c. Pertumbuhan Perusahaan (X3)

Pengukuran yang digunakan untuk menghitung pertumbuhan perusahaan yaitu dengan menggunakan rumus sebagai berikut:

Keterangan:

$$
\text { Growth }=\frac{\text { Total Asset }(\mathrm{t})-\text { Total Asset }(\mathrm{t}-1)}{\text { Total Asset }(\mathrm{t}-1)} \times 100 \%
$$

Total Asset $(\mathrm{t})=$ total aset periode tahun berjalan

Total Asset $(\mathrm{t}-1)=$ total aset periode tahun sebelumnya

d. Konsentrasi Kepemilikan Manajerial (X4)

Kepemilikan manajerial dapat dihitung menggunakan rumus sebagai berikut:

$$
\text { Kepemilikan Manajerial }=\frac{\text { jumlah saham yang dimiliki manajemen }}{\text { jumlah saham yang beredar }}
$$

\section{e. Jenis KAP (X5)}

Pengukuran jenis KAP menggunakan variabel dummy yang digunakan untuk mengkuantitatifkan variabel yang bersifat kualitatif. Variabel tersebut diukur menggunakan angka dummy sebagai berikut:

Skor 1 (satu) = KAP yang berafiliasi dengan Big Four

Skor 0 (nol) = KAP non-Big Four

Metode Analisis

\section{Statistik Deskriptif}

Analisis statistik deskriptif bertujuan untuk mendeskripsikan suatu data agar mudah dipahami. Analisis statistik deskriptif dapat digunakan untuk melihat nilai minimum, maksimum, rata-rata (mean), serta simpangan baku (standar deviasi) dari variabel penelitian yang diteliti (Nazaruddin dan Basuki, 2017).

\section{Uji Asumsi Klasik}

a. Uji Normalitas

Uji normalitas digunakan untuk menguji adanya variabel pengganggu atau tingkat residual memiliki distribusi normal dalam model regresi. Penelitian ini menggunakan pengujian normalitas one-sample Kolmogorov-Smirnow test (K-S), menggunakan kriteria $\alpha=0,05$ dengan syarat jika sig $>\alpha$ maka residual dapat dikatakan berdistribusi normal (Ghozali, 2016).

\section{b. Uji Multikolinieritas}

Uji multikolinieritas bertujuan untuk menguji apakah terdapat korelasi antar variabel bebas dalam model regresi. Dalam penelitian ini, nilai tolerance dan variance inflation factors (VIF) digunakan untuk mendeteksi multikolinieritas. Model dinyatakan tidak mengandung 
multikolinieritas jika nilai Variance Inflation Factors (VIF) $<10$ dan nilai TOL (tolerance) $>0,10$ (Ghozali, 2016).

\section{c. Uji Autokorelasi}

Uji autokorelasi dalam penelitian ini bertujuan untuk melihat ada atau tidaknya masalah penyimpangan dalam asumsi klasik autokorelasi yaitu korelasi yang terjadi antar residual pada satu pengamatan dengan pengamatan lain pada model regresi (Nazaruddin dan Basuki, 2017). Untuk mendeteksi hal tersebut, penelitian ini menggunakan uji Durbin-Watson (Uji D-W).

Menurut Nazaruddin dan Basuki (2017) metode yang digunakan dalam pengujian Durbin Watson memiliki ketentuan-ketentuan sebagai berikut:

1) Jika d lebih kecil dari $\mathrm{dL}$ atau lebih besar dari (4-dL), maka hipotesis nol ditolak, yang berarti terdapat autokorelasi.

2) Jika d terletak di antara dU dan (4-dU), maka hipotesis nol diterima, yang artinya tidak terdapat autokorelasi

3) Jika d terletak antara dL dan dU atau antara (4-dU) dan (4-dL), maka tidak menghasilkan kesimpulan yang pasti.

\section{d. Uji Heteroskedastisitas}

Uji heteroskedastisitas bertujuan untuk menguji apakah dalam model regresi terjadi ketidaksamaan variance dari residual satu pengamatan ke pengamatan yang lain (Ghozali,2016). Salah satu cara untuk mendeteksi ada atau tidaknya heteroskedastisitas adalah menggunakan uji gletser. Uji ini dilakukan untuk mengetahui adanya penyimpangan syarat-syarat asumsi klasik pada model regresi dimana syarat yang harus dipenuhi model regresi adalah tidak adanya masalah heteroskedastisitas (Nazaruddin dan Basuki, 2017). Jika nilai signifikansi $>\alpha(0,05)$ maka tidak terjadi masalah heterosdesatisitas.

Uji Hipotesis dan Analisa Data

\section{Analisis Regresi}

Pengujian biological asset intensity, ukuran perusahaan, pertumbuhan perusahaan, konsentrasi kepemilikan manajerial, dan jenis KAP terhadap pengungkapan aset biologis menggunakan analisis regresi berganda, dengan model sebagai berikut:

Keterangan:

$$
\mathrm{Y}^{\prime}=\mathrm{a}+\mathrm{b} 1 \mathrm{X} 1+\mathrm{b} 2 \mathrm{X} 2+\mathrm{b} 3 \mathrm{X} 3+\mathrm{b} 4 \mathrm{X} 4+\mathrm{b} 5 \mathrm{X} 5+\mathrm{e}
$$

Y' $\quad=$ Pengungkapan Aset Biologis

a $\quad=$ intercept (konstanta) yaitu nilai perkiraan $\mathrm{Y}$ jika $\mathrm{X}=0$

b1 $\quad=$ Koefisien regresi X1

b2 $=$ Koefisien regresi $\mathrm{X} 2$

b3 = Koefisien regresi $\mathrm{X} 3$

$\mathrm{b} 4 \quad=$ Koefisien regresi $\mathrm{X} 4$

b5 $\quad=$ Koefisien regresi X5

$\mathrm{e} \quad=$ Nilai residu (nilai-nilai dari variabel lain yang tidak dimasukkan dalam persamaan

\section{Uji Koefisien Determinasi}

Uji koefisien determinasi bertujuan untuk mengetahui pengaruh antara variabel bebas (independen) terhadap variabel terikat (dependen). Presentase total variance dapat ditentukan 
dengan uji koefisien determinasi (R2). Pengujian ini dilakukan dengan melihat nilai koefisien determinasi R2.

Nilai yang kecil menunjukkan kemampuan variabel-variabel independen dalam menjelaskan variabel dependen sangat kecil. Nilai yang mendekati satu berarti variabel-variabel independen memberikan hampir semua informasi yang dibutuhkan untuk memprediksi variasi variabel dependen (Nazaruddin dan Basuki, 2017).

\section{Uji Statistik F}

Uji statistik F dalam penelitian ini bertujuan untuk melihat apakah seluruh variabel bebas (independen) berpengaruh secara keseluruhan terhadap variabel terikat (dependen) yang disajikan dalam Tabel ANOVA (Nazaruddin dan Basuki, 2017). Uji statistik F ini menggunakan tingkat $\alpha$ sebesar $5 \%$ dengan kriteria sebagai berikut:

a) Jika nilai signifikan > 0,05 maka variabel independen secara simultan tidak berpengaruh terhadap variabel dependen.

b) Jika nilai signifikan $<0,05$ maka variabel independen secara simultan berpengaruh terhadap variabel dependen.

4. Uji Statistik t

Uji statistik t dalam penelitian ini bertujuan untuk melihat pengaruh setiap variabel independen terhadap variabel dependen secara parsial yang ditunjukkan pada tabel koefisien (Nazaruddin dan Basuki, 2017). Pengujian ini menggunakan tingkat $\alpha$ sebesar 0,05. Apabila nilai signifikansi atau p-value > 0,05 dan atau koefisien regresi berlawanan arah dengan hipotesis, maka hipotesis alternatif tidak terdukung atau menunjukkan bahwa secara parsial variabel independen tidak berpengaruh terhadap variabel dependen.

Apabila nilai signifikansi atau p-value $<0,05$ dan koefisiensi regresi searah dengan hipotesis, maka hipotesis alternatif terdukung atau menunjukkan bahwa secara parsial variabel independen berpengaruh terhadap variabel dependen.

\section{HASIL DAN PEMBAHASAN}

\section{Pengujian Hipotesis 1}

Hasil penelitian variabel biological asset intensity memiliki koefisien regresi (beta) sebesar 0,231 dan nilai sig sebesar 0,060. Tingkat signifikansi variabel biological asset intensity lebih besar dari alpha 0,05 sehingga dapat dikatakan bahwa biological asset intensity tidak berpengaruh terhadap pengungkapan aset biologis. Dengan demikian maka hipotesis pertama (H1) yang menjelaskan bahwa biological asset intensity berpengaruh positif terhadap pengungkapan aset biologis ditolak.

Biological asset intensity tidak berpengaruh terhadap pengungkapan aset biologis karena aset biologis merupakan aset utama yang dimiliki oleh perusahaan agrikultur sehingga perusahaan agrikultur tetap akan mengungkapkan aset biologisnya. Oleh sebab itu, investor tidak menjadikan pengaruh biological asset intensity (intensitas aset biologis) terhadap pengungkapan aset biologis yang dilakukan oleh perusahaan agrikultur sebagai pusat perhatian dalam pengambilan keputusan investasi pada perusahaan tersebut.

Penelitian ini tidak sejalan dengan penelitian yang dilakukan oleh Rute and Patricia (2014), Amelia (2017), dan Kusumadewi (2018) yang menunjukkan bahwa biological asset intensity berpengaruh terhadap pengungkapan aset biologis. 


\section{Pengujian Hipotesis 2}

Hasil penelitian variabel ukuran perusahaan memiliki koefisien regresi (beta) sebesar -0,189 dan nilai sig sebesar 0,189 . Tingkat signifikansi variabel ukuran perusahaan lebih besar dari alpha 0,05 sehingga dapat dikatakan bahwa ukuran perusahaan tidak berpengaruh terhadap pengungkapan aset biologis. Dengan demikian maka hipotesis kedua (H2) yang menjelaskan bahwa ukuran perusahaan berpengaruh positif terhadap pengungkapan aset biologis ditolak.

Ukuran perusahaan tidak berpengaruh terhadap pengungkapan aset biologis karena perusahaan agrikultur yang memiliki total aset dalam jumlah yang besar tidak menjamin memberikan pengungkapan aset biologis yang lebih luas dibandingkan dengan perusahaan agrikultur yang memiliki total aset yang kecil. Selain itu, perusahaan agrikultur dengan ukuran besar juga tidak selalu memiliki jumlah intensitas aset biologis yang tinggi. Oleh sebab itu, investor dalam mengambil keputusan untuk menanamkan modalnya ke perusahaan agrikultur tidak menjadikan pengaruh ukuran perusahaan sebagai tolok ukur dalam keluasan pengungkapan aset biologis yang dilakukan oleh perusahaan tersebut.

Penelitian ini sejalan dengan penelitian yang dilakukan oleh Kusumadewi (2018) yang menyatakan bahwa ukuran perusahaan tidak berpengaruh terhadap pengungkapan aset biologis, dan penelitian yang dilakukan oleh Khairiah dan Fuadi (2017) yang menyatakan bahwa ukuran perusahaan tidak berpengaruh terhadap pengungkapan sukarela.

\section{Pengujian Hipotesis 3}

Hasil penelitian variabel pertumbuhan perusahaan memiliki koefisien regresi (beta) sebesar 0,082 dan nilai sig sebesar 0,438. Tingkat signifikansi variabel ukuran perusahaan lebih besar dari alpha 0,05 sehingga dapat dikatakan bahwa pertumbuhan perusahaan tidak berpengaruh terhadap pengungkapan aset biologis. Dengan demikian maka hipotesis ketiga (H3) yang menjelaskan bahwa pertumbuhan perusahaan berpengaruh positif terhadap pengungkapan aset biologis ditolak.

Pertumbuhan perusahaan tidak berpengaruh terhadap pengungkapan aset biologis karena tinggi atau rendahnya tingkat pertumbuhan perusahaan agrikultur tidak berpengaruh terhadap keluasan pengungkapan aset biologis. Perusahaan agrikultur yang memiliki pertumbuhan yang tinggi tidak menjamin memberikan pengungkapan aset biologis secara luas dibandingkan dengan perusahaan agrikultur yang memiliki tingkat pertumbuhan yang rendah. Oleh sebab itu, pengaruh pertumbuhan perusahaan agrikultur terhadap pengungkapan aset biologis yang dilakukan oleh perusahaan tersebut tidak menjadi pusat perhatian bagi investor dalam mengambil keputusan investasi.

Penelitian ini sejalan dengan penelitian yang dilakukan oleh Evandini (2014) dan Tasya (2016) yang menyatakan bahwa pertumbuhan perusahaan tidak berpengaruh terhadap pengungkapan Corporate Social Responsibility (CSR).

\section{Pengujian Hipotesis 4}

Hasil penelitian variabel konsentrasi kepemilikan manajerial memiliki koefisien regresi (beta) sebesar 0,263 dan nilai sig sebesar 0,026. Tingkat signifikansi variabel konsentrasi kepemilikan manajerial lebih kecil dari alpha 0,05 sehingga dapat dikatakan bahwa konsentrasi kepemilikan manajerial berpengaruh positif terhadap pengungkapan aset biologis. Dengan demikian maka hipotesis keempat (H4) yang menjelaskan bahwa konsentrasi kepemilikan manajerial berpengaruh positif terhadap pengungkapan aset biologis diterima.

Konsentrasi kepemilikan manajerial berpengaruh positif terhadap pengungkapan aset biologis karena manajer yang memiliki andil dalam permodalan perusahaan akan melaksanakan tugasnya sebaik mungkin tidak hanya untuk kepentingan sendiri tetapi juga demi keberlangsungan perusahaan agar dapat bertahan dan terus berkembang, serta dapat menjadi pemenang dalam persaingan. Oleh sebab itu, dengan adanya kepemilikan manajerial, manajer akan selalu berupaya 
agar perusahaan agrikultur memiliki nilai dan kinerja yang baik. Perusahaan yang memiliki nilai dan kinerja yang baik akan semakin luas dan banyak dalam mengungkapkan aset biologisnya.

Pengungkapan aset biologis yang luas tersebut, yang disebabkan oleh adanya pengaruh konsentrasi kepemilikan manajerial dapat menarik perhatian berbagai pihak terutama investor. Investor akan menjadikan hal tersebut sebagai pusat perhatian dan bahan pertimbangan dalam mengambil keputusan untuk menanamkan modalnya ke perusahaan agrikultur tersebut.

Penelitian ini sejalan dengan penelitian yang dilakukan oleh Aini dan Syafruddin (2015) yang menunjukkan bahwa kepemilikan manajerial berpengaruh terhadap pengungkapan sukarela. Kemudian penelitian yang dilakukan oleh 'Amal (2011) dan Edison (2017) yang menunjukkan bahwa kepemilikan manajerial berpengaruh terhadap pengungkapan Corporate Social Responsibility (CSR).

\section{Pengujian Hipotesis 5}

Hasil penelitian variabel jenis KAP memiliki koefisien regresi (beta) sebesar 0,275 dan nilai sig sebesar 0,028. Tingkat signifikansi variabel jenis KAP lebih kecil dari alpha 0,05 sehingga dapat dikatakan bahwa jenis KAP berpengaruh positif terhadap pengungkapan aset biologis. Dengan demikian maka hipotesis kelima (H5) yang menjelaskan bahwa jenis KAP berpengaruh positif terhadap pengungkapan aset biologis diterima.

Jenis KAP berpengaruh positif terhadap pengungkapan aset biologis karena Kantor Akuntan Publik (KAP) yang berafiliasi dengan KAP Big Four lebih dipercaya dibandingkan dengan KAP non-Big Four. KAP Big Four merupakan auditor besar yang memiliki reputasi yang baik serta independensi yang tinggi, sehingga untuk menjaga reputasinya agar tetap baik maka KAP Big Four akan memberikan hasil audit yang berkualitas dan memberikan hasil pengungkapkan aset biologis yang luas pada perusahaan agrikultur yang diaudit.

Pengungkapan aset biologis yang luas tersebut, yang disebabkan oleh adanya pengaruh jenis KAP dapat menarik perhatian berbagai pihak terutama investor. Investor akan menjadikan hal tersebut sebagai pusat perhatian dan bahan pertimbangan dalam mengambil keputusan untuk menanamkan modalnya ke perusahaan agrikultur tersebut.

Penelitian ini sejalan dengan penelitian yang dilakukan oleh Hodgdon, dkk (2009) dan Nuryaman (2009) yang menyatakan bahwa terdapat hubungan antara kepatuhan pengungkapan dengan perusahaan yang diaudit oleh Kantor Akuntan Publik Big Four.

\section{KESIMPULAN}

Penelitian ini bertujuan untuk menguji dan mendapatkan bukti secara empiris mengenai pengaruh biological asset intensity, ukuran perusahaan, pertumbuhan perusahaan, konsentrasi kepemilikan manajerial, dan jenis KAP terhadap pengungkapan aset biologis. Sampel yang digunakan dalam penelitian ini adalah sampel dari perusahaan agrikultur yang terdaftar di Bursa Efek Indonesia (BEI) periode 2014-2017. Berdasarkan hasil penelitian dan pembahasan, maka dapat disimpulkan biological asset intensity tidak berpengaruh terhadap pengungkapan aset biologis pada perusahaan agrikultur yang terdaftar di Bursa Efek Indonesia (BEI) periode 2014-2017. Ukuran perusahaan tidak berpengaruh terhadap pengungkapan aset biologis pada perusahaan agrikultur yang terdaftar di Bursa Efek Indonesia (BEI) periode 2014-2017. Pertumbuhan perusahaan tidak berpengaruh terhadap pengungkapan aset biologis pada perusahaan agrikultur yang terdaftar di Bursa Efek Indonesia (BEI) periode 2014-2017. Konsentrasi kepemilikan manajerial berpengaruh positif terhadap pengungkapan aset biologis pada perusahaan agrikultur yang terdaftar di Bursa Efek Indonesia (BEI) periode 2014-2017. Jenis KAP berpengaruh positif terhadap pengungkapan aset biologis pada perusahaan agrikultur yang terdaftar di Bursa Efek Indonesia (BEI) periode 2014-2017.

Saran untuk penelitian selanjutnya dapat menambah variabel lain yang mungkin berpengaruh terhadap pengungkapan aset biologis, misalnya: profitabilitas, leverage, dan umur perusahaan. 
Penelitian selanjutnya dapat menggunakan periode pengamatan tahun yang terbaru dan memperpanjang tahun pengamatan penelitian agar lebih memberikan gambaran terkini mengenai pengungkapan aset biologis. Perusahaan agrikultur diharapkan lebih rinci dalam mengungkapkan aset biologis yang dikelola oleh perusahaannya. Pengungkapan secara rinci tersebut dimulai dari pengungkapan awal, masa panen, diproduksi menjadi produk agrikultur, hingga aset tersebut mengalami penghentian karena mati atau tidak berkembang biak lagi. Hal tersebut perlu dilakukan agar pemakai laporan keuangan dapat mengetahui secara rinci dan jelas.

\section{DAFTAR PUSTAKA}

'Amal, M. I. (2011). Pengaruh Manajemen Laba, Kepemilikan Manajerial, Ukuran Perusahaan, dan Profitabilitas terhadap Pengungkapan Tanggung Jawab Sosial dan Lingkungan. Skripsi. Universitas Diponegoro.

Abdullah, R. A. (2011). Perlakuan Akuntansi Aset Biologis PT. Perkebunan Nusantara XIV Makassar (Persero). Skripsi. Fakultas Ekonomi Universitas Hasanuddin.

Aini, P. N. \& Syafruddin, M. (2015). Pengaruh Kepemilikan Manajerial terhadap Pengungkapan Sukarela dengan Efektivitas Komite Audit sebagai Variabel Moderasi. Jurnal Of Accounting Diponegoro, 4 (2), 2337-3806.

Amelia, D. (2016). Pengaruh Profitabilitas, Leverage, Pertumbuhan Perusahaan, Tipe Industri, dan Kepemilikkan Saham Publik terhadap Corporate Social Responsibility Disclosure (Pada Industri Pertambangan yang terdaftar di Bursa Efek Indonesia periode Tahun 20102014). Skripsi. Universitas Esa Unggul.

Amelia, F. (2017). Pengaruh Biological Asset Intensity, Ukuran Perusahaan, Konsentrasi Kepemilikan, dan Jenis KAP terhadap Pengungkapan Aset Biologis (Pada Perusahaan Agrikultur yang terdaftar di Bursa Efek Indonesia Periode 2012-2015). Tesis. Universitas Andalas.

Aprianingsih, A. (2016). Pengaruh Penerapan Good Corporate Governance, Struktur Kepemilikan, dan Ukuran Perusahaan terhadap Kinerja Keuangan Perbankan. Jurnal Profita, 11 (2).

Choi, F. (2005). International Accounting, New Jersey: Prentice Hall.

Christiawan, Y.J. \& Tarigan, J. (2007). Kepemilikan Manajerial: Kebijakan Hutang, Kinerja dan Nilai Perusahaan. Jurnal Akuntansi dan Keuangan. 9 (1).

Cormier, et al. (2005). Environmental Disclosure Quality in Large German Companies: Economic Incentives, Public Pressures or Institutional Conditions?. European Accounting Review, 14 (1).

Edison, A. (2017). Struktur Kepemilikan Asing, Kepemilikan Institusional dan Kepemilikan Manajerial Pengaruhnya terhadap Luas Pengungkapan Corporate Social Responsibility (CSR) (Pada Perusahaan Sektor Utama yang terdaftar di Bursa Efek Indonesia Tahun 2013-2014). Jurnal Bisnis dan Manajemen, 11 (2), 164-175.

Effendi, F. R. \& Hapsari, D. W. (2015). Analisis Pengaruh Profitabilitas, Ukuran Perusahaan, dan Pertumbuhan Perusahaan terhadap Pengungkapan Tanggung Jawab Sosial Perusahaan. $e$ Proceeding of Management, 2 (3), 3409-3416.

Evandini, C. D. (2014). Faktor - Faktor Yang Berpengaruh terhadap Pengungkapan Tanggung Jawab Sosial Perusahaan Pada Perusahaan Manufaktur yang Terdaftar Di BEI. Diponegoro Journal Of Accounting, 3(3):1-11.

Financial Accounting Standards Board (FASB). (1984). Statement of Financial Accounting Concepts No.5: Recognition and Measurement in Financial Statement of Business Enterprises, Stamford, Connecticut.

Freedman, M. \& Jaggi, B. (1984). Strategic Management: A Stakeholder Approach. Boston: Pitman.

Ghozali, I. \& Chariri, A. (2007). Teori Akuntansi. Badan Penerbit Universitas Diponegoro, Semarang. 
Ghozali, I. (2016). Aplikasi Analisis Multivariate Lanjutan dengan Program SPSS. Semarang: Badan Penerbitan Universitas Diponogoro.

Hodgdon, dkk. (2009). Compliance with International Financial Reporting Standards and Auditor Choice: New Evidence on the Importance of the Statutory Audit. The International Journal of Accounting, 44: 33-55.

Ikatan Akuntansi Indonesia. (2012). Standar Akuntansi Keuangan, Jakarta: Salemba Empat.

Jensen, M. C. \& Meckling, W. H. (1976). Theory of The Firm: Managerial Behaviour, Agency Costs and Ownership Structure. Journal of Financial Economics, 3(4), 305-360.

Kallapur, S. \& Trombley, M. A. (2001). The Association Between Investment Opportunity Set Proxies and Realized Growth. Journal of Business \& Accounting, 505-519.

Khairiah \& Fuadi. (2017). Faktor-Faktor Yang Mempengaruhi Pengungkapan Sukarela Dalam Laporan Tahunan (Studi Pada Perbankan Syariah Di Indonesia). Jurnal Ilmiah Mahasiswa Ekonomi Akuntansi (JIMEKA), 2(1), 63-72.

Kiryanto \& Supriyanto, E. (2006). Pengaruh Moderasi Size terhadap Hubungan Antara Konflik Kepentingan dan Konservatisme Akuntansi. SNA IX. Ikatan Akuntan Indonesia.

Kusumadewi, A. A. (2018). Pengaruh Biological Asset Intensity dan Ukuran Perusahaan terhadap Pengungkapan Aset Biologis (Pada Perusahaan Perkebunan yang Terdaftar di BEI Periode 2017). Skripsi. Universitas Pasundan.

Machfoedz, M. (1994). Financial Ratio Characteristic Analysis and The Prediction of Earning Change in Indonesia. Kelola, 7, 114-133.

Martani, D. (2011). Disampaikan dalam seminar IAS 41: Agriculture IAS 41, Jakarta: IAI.

Munsaidah, S. dkk. (2016). Analisis Pengaruh Firm Size, Age, Profitabilitas, Leverage, dan Growth Perusahaan terhadap Corporate Social Responsibility (CSR) (Pada Perusahaan Property dan Real Estate yang terdaftar di Bursa Efek Indonesia Pada Tahun 2010-2014). Journal Of Accounting, 2(2).

Nazaruddin, I. \& Basuki, A. T. (2017). Analisis Statistik Dengan SPSS. Yogyakarta: Danisa Media.

Nuryaman. (2009). Pengaruh Konsentrasi Kepemilikan, Ukuran Perusahaan, dan Mekanisme Corporate Governance terhadap Pengungkapan Sukarela. Jurnal Akutansi dan Keuangan Indonesia, 6(1): 89-116.

Owusu-Ansah, S. (1998). The Impact of Corporate Attribites on The Extent of Mandatory Disclosure and Reporting by Listed Companies in Zimbabwe. International Journal of Accounting, 33(5), 605-631.

Pratiwi, L. (2014). Analisis Pengaruh Struktur Good Corporate Governance dan Kepemilikan Manajerial terhadap Kinerja Perusahaan. Skripsi. Univesitas Diponegoro.

Putri, S. U. (2011). Analysing Factors Influencing Intangible Asset Disclosure (Study In SouthEast Asia And Australia Telecommunication Industry). Skripsi Tidak Dipublikasikan. Fakultas Ekonomika dan Bisnis. Universitas Diponegoro.

Rachmawati, S. (2008). Pengaruh Faktor Internal dan Eksternal Perusahaan terhadap Audit Delay dan Timeliness. Jurnal Akuntansi dan Keuangan, 10 (1).

Riyanto, B. (2008). Dasar-dasar Pembelanjaan Perusahaan. Yogyakarta: Penerbit GPFE.

Rute, G. \& Patrícia, L. (2014). Firm-specific Determinants of Agricultural Financial Reporting. Procedia - Social and Behavioral Sciences. Elsevier 110, 470-481.

Santoso, S. (2010). Statistik Multivariate, Edisi Revisi, Jakarta: PT. Gramedia.

Sari, R. A. (2012). Pengaruh Karakteristik Perusahaan Terhadap Corporate Social Responsibility Disclosure (Pada Perusahaan Manufaktur yang terdaftar di Bursa Efek Indonesia). Jurnal Nominal, 1 (1), 125-138.

Sefiana, E. (2009). Pengaruh Penerapan Corporate Governance terhadap Manajemen Laba Pada Perusahaan Manufaktur yang Go Public di BEI. Jurnal Riset Akuntansi. Fakultas EkonomiUniversitas Gunadarma, 9 (2).

Setiawan, R. (2009). Pengaruh Growth Opportunity dan Ukuran Perusahaan terhadap Profitabilitas Perusahaan Industri Manufaktur di Indonesia. Jurnal Ekonomi, 19 (2), 163173. 
Silva, R. dkk. (2012). Konvergensi dengan Standar Akuntansi Internasional: Analisis Pengungkapan Aset Biologis IAS 41. University of Porto.

Soliha \& Taswan. (2002). Pengaruh Kebijakan Hutang Terhadap Nilai Perusahaan Serta Beberapa Faktor yang Memengaruhinya. Jurnal Ekonomi dan Bisnis, 1 (1). STIE STIKUBANK Semarang.

Sugiarto, M. (2011). Pengaruh Struktur Kepemilikan dan Kebijakan Dividen terhadap Nilai Perusahaan dengan Kebijakan Hutang sebagai Intervening. Jurnal Akuntansi Kontemporer. $3(1)$.

Tasya, Elvira. (2016). Pengaruh Pertumbuhan Perusahaaan, Profitabilitas dan Leverage terhadap Pengungkapan Tanggung Jawab Sosial Perusahaan (Pada Perusahaan Manufaktur Yang Terdaftar di Bursa Efek Indonesia Tahun 2010-2014). Skripsi. Universitas Negeri Padang.

Widowati, A. I. (2011). Faktor-Faktor yang Mempengaruhi Pelaporan Aset Tak Berwujud Pada Perusahaan yang terdaftar di BEI. Paper disajikan pada Seminar Nasional Update Ekonomi, Akuntansi dan Bisnis Indonesia 2011. Fakultas Ekonomi. Universitas Islam Indonesia. 28 Juni 2011. ISSN 2088-6551. 